\title{
НАПРЯМКИ ТА ІНСТРУМЕНТИ ДЕРЖАВНОГО РЕГУЛЮВАННЯ СТРАТЕГІЧНОГО РОЗВИТКУ ЗАЛІЗНИЧНОГО ТРАНСПОРТУ
}

Токмакова I.В., о.е.н., професор,

Овчиннікова В.О., д.е.н., професор,

Корінь М.В., д.е.н., доцент (УкрДУЗТ)

В статті встановлено, щзо для формування стратегічних переваг залізничного транспорту, заснованих на інтелектуальному лідерстві галузі, необхідною є державна підтримка. Проведене дослідження дозволило вказати на недостатню ефективність діючої наразі державної політики регулювання залізничного транспорту. Грунтуючись на иьому, сформовано напрямки державного регулювання розвитку залізничного транспорту, які враховують стратегічні орієнтири розвитку галузі та розкривають інструменти державної підтримки прочесів формування стратегічних переваг за такими складовими розвитку, як інноваційно-виробнича, інвестиційна, енергетична, екологічна, сочіальна та міжнародна складова.

Ключові слова: залізничний транспорт, державне регулювання, розвиток, інструменти, стратегія розвитку.

\section{НАПРАВЛЕНИЯ И ИНСТРУМЕНТЫ ГОСУДАРСТВЕННОГО РЕГУЛИРОВАНИЯ СТРАТЕГИЧЕСКОГО РАЗВИТИЯ ЖЕЛЕЗНОДОРОЖНОГО ТРАНСПОРТА}

\author{
Токмакова И.В., о.э.н., профессор, \\ Овчинникова В.А., о.э.н., профессор, \\ Коринь М.В., о.э.н., доцент (УкрДУЗТ)
}

В статье установлено, что для формирования стратегических преимущееств железнодорожного транспорта, основанных на интеллектуальном лидерстве отрасли, необходима государственная поддержка. Проведенное исследование позволило указать на недостаточную эффективность действующей в настоящее время государственной политики регулирования железнодорожного транспорта. Основываясь на этом, сформированы направления государственного регулирования развития железнодорожного транспорта, учитывающие стратегические ориентиры развития отрасли и раскрывающие инструменты государственной поддержки процессов формирования стратегических преимуществ по таким составляющим развития, как инновационно-производственная, инвестиционная, энергетическая, экологическая, сочиальная и международная составляющая.

Ключевые слова: жжелезнодорожный транспорт, государственное регулирование, развитие, инструменты, стратегия развития.

(C) Токмакова I.B., Овчинникова В.О., Корінь М.В. 


\title{
DIRECTIONS AND INSTRUMENTS OF STATE REGULATION OF STRATEGIC DEVELOPMENT OF RAILWAY TRANSPORT
}

\author{
Tokmakova I.V., Doctor of Economics, Professor, \\ Ovchynnikova V.A., Doctor of Economics, Professor, \\ Korin M.V., Doctor of Economics, Associate Professor (UUofRT)
}

It is established that in order to shape the strategic advantages of railway transport based on the intellectual leadership of the industry, in the highly competitive EU market, state support of the processes of ensuring strategic changes in the rail transport is needed, which should create a qualitative basis for the competitiveness of the industry in the international and domestic markets. services. The study of the peculiarities of state regulation of railway transport in developed countries and the development of regulatory support for the activities of Ukrainian railways, showed the insufficient effectiveness of the current state policy of regulation of railway transport. The biggest mistake in the development and implementation of reforms in the Ukrainian railways was the lack of a script approach to drawing up the Rail Transport Development Strategy, which provides a description of not only specific targeted programs aimed at achieving the overall goal of railway development, but also detailing mechanisms and instruments of state regulation of the processes. development. Considering the chosen priorities for the implementation of reforms and the need for strategic changes in the railway industry in order to improve the position in the European transport and logistics market, the feasibility of changing the current principles and instruments of state regulation of railway transport development is substantiated. On this basis, the directions of state regulation of railway transport development have been formed, which take into account the strategic guidelines for the development of the industry and reveal the instruments of state support of the processes of formation of strategic advantages for such components of development as innovation-production, investment, energy, environmental, social and international. The implementation of the proposed model of public administration will facilitate the implementation of strategic changes in the activity of Ukrainian railways and the achievement of leading positions in the European market of transport and logistics services.

Key words: railway transport, state regulation, development, tools, development strategy.

Постановка проблеми. Специфіка втручання держави в процеси розвитку залізничного транспорту полягає в тому, що залізниця виступає однією з базових галузей економіки країни. Загальновідомим $\epsilon$ той факт, що залізничний транспорт забезпечує близько $60 \%$ вантажних перевезень у країні i майже 300 тис. чоловік робочими місцями, формуючи при цьому значну частину податкових платежів до державного бюджету країни. Саме тому трансформаційні зміни в галузі вимагають від держави реалізації більш дієвих моделей, методів та інструментів регулювання процесів економічного зростання залізничного транспорту відповідно до встановлених стратегічних орієнтирів.

Аналіз останніх досліджсень $i$ публікацій та виділення невирішених частин загальної проблеми. Проблемам розвитку залізничного транспорту України та аспектам його державного регулювання присвячено багато робіт зарубіжних і вітчизняних авторів, зокрема Диканя В. Л., Островерх Г. Є., Полякової О. М., Шраменко О. В., Дикань О. В., Корінь М. В., Обруч Г. В.,

Вісник економіки транспорту і промисловості № 69, 2020 
Токмакової І.В., Овчиннікової В. О. та інших [1-6].

Разом 3 тим необхідні нові дієві пропозиції, що визначать напрямки та інструменти державного регулювання процесів економічного зростання залізничного транспорту відповідно до умов макро- та мікросередовища.

Тому,

метою

cmammi $\epsilon$ опрацювання напрямків та інструментів державного регулювання стратегічного розвитку залізничного транспорту України.

\section{Виклад основного}

матеріалу. Сучасною економічною наукою розроблено досить значна кількість підходів до структурування методів, інструментів і меж необхідного втручання держави в економічні процеси.

Що стосується методів державного регулювання економіки в цілому, то більшість підходів грунтується на їх групуванні за формою (прямі та непрямі) та способом впливу (адміністративні, морально-етичні, економічні, правові). Так, Литвин Ю.О., розглядаючи методи державного регулювання сільського господарства, виділяє адміністративні, правові, економічні методи державного регулювання аграрної економіки та відповідні їм інструменти [7] (рис. 1).

Положенцева К.Л. наводить більш розширену систематизацію інструментів регулювання державної політики в аграрній економіці, виділяючи бюджетні (фінансування сільськогосподарських виробництв, фінансування капітальних вкладень, субсидіювання процентних ставок, лізинг в АПК), цінові (ринкові, контрольні, гарантовані, захисні ціни тощо), податкові (податки, податкові пільги, спрощена система оподаткування тощо), соціальні (підвищення рівня життя, медичне обслуговування тощо), наукові (фундаментальні наукові дослідження, інноваційні програми розвитку АПК, підготовка фахівців тощо), кредитні (сезонне, інвестиційне, іпотечне, вексельне кредитування тощо), зовнішньоекономічні (заохочення експорту, нетарифне регулювання імпорту сільгосппродукції тощо) інструменти регулювання та інструменту регулювання доходів (декларування цін, встановлення граничного рівня рентабельності, еквівалентний міжгалузевий обмін тощо) [8].

Динаєв Т.Н. зазначає, що державне регулювання підприємницької діяльності може реалізовуватися в різних формах, що залежить від масштабів інструментів, змісту та характеру заходів з регулювання. Відповідно до цього даний науковець пропонує виділяти адміністративнозаконодавчі (закони, заборони, заходи примусу, державне субсидіювання, державне підприємництво) та фінансовоекономічні (кредитно-грошові, бюджетноподаткові, індикативне планування) методи державного регулювання [9].

Досліджуючи аспекти державного стимулювання розвитку зовнішньоекономічної діяльності підприємств, Борисенко О.П. наводить досить розширену класифікацію методів державного регулювання даного виду діяльності, систематизуючи їх за такими класифікаційними ознаками, як форма впливу, спосіб здійснення, пріоритетність застосування, напрям дії, масштаб покриття, функція управління, призначення, термін дії, глибина втручання, термін реагування, спосіб прояву тощо [10]. Однак, попри це, представлена класифікація має досить узагальнюючий характер, а деякі виділені ознаки дублюють одна одну.

Гончаренко І.Г. у своїй роботі [11], використовуючи матричний підхід, наводить методи державного регулювання соціально-економічного розвитку країни на регіональному рівні: методи бюджетноподаткової політики, нормативно-правові й інституційні методи державного регулювання соціально-економічного розвитку регіону. 


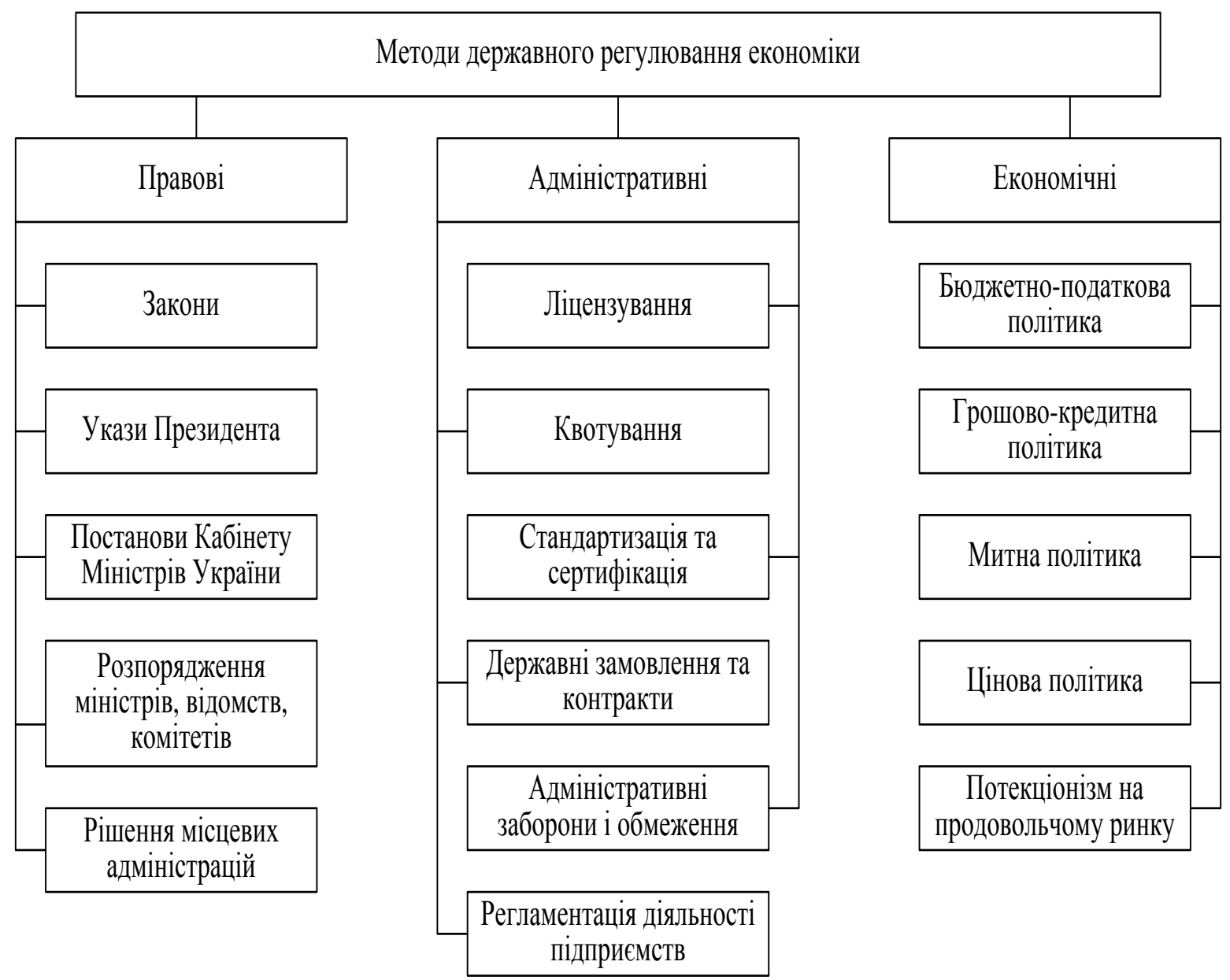

Рис. 1. Методи та інструменти державного регулювання аграрної економіки [7]

Що стосується підходів до систематизації інструментів державного регулювання транспортного комплексу, то одним із них є підхід, виділений Грабельниковим А.В. Науковець пропонує методи державного регулювання транспорту поділяти на прямі й непрямі, включаючи до першої групи інструменти адміністративного характеру, а до другої інструменти бюджетного, податкового та грошово-кредитного регулювання [12]. На думку автора дисертації, такий розподіл інструментів державного регулювання транспортного комплексу не визначає специфіки регулювання транспортного процесу, а тому може бути застосований i по відношенню до інших суб'єктів господарювання країни.

Плікус І.Й. визначає методи державного регулювання діяльності підприємств у галузі пасажирського автотранспорту:

адміністративні, економічні та соціально-психологічні. Першу групу методів науковець поділяє на методи регламентування (закони України в сфері регулювання діяльності автомобільного транспорту, ліцензійні умови) та нормування (нормативні акти, що встановлюють норми споживання ресурсів на транспорті). Економічні ж методи Плікус І.Й. поділяє на примусові та заохочувальні, а до соціальнопсихологічних відносить наявність пільгових пасажирів [13].

Досить цікавим $є$ підхід до формування системи державного регулювання діяльності транспорту, запропонований Дикань О.В., за яким даним науковцем виділяються правові, адміністративні та економічні методи державного регулювання, а також розкриваються інструменти правового,

Вісник економіки транспорту і промисловості № 69, 2020 
організаційного, інформаційного та зокрема, доцільно відзначити, що економічного забезпечення державного більшість із них засновані на розподілі регулювання транспорту [14]. ㅎсуунтів залежно від способу Узагальнюючи підходи до реалізації політики державного систематизації методів, форм та регулювання, а саме: виділенні інструментів державного регулювання інструментів в рамках адміністративних, (табл. 1) як економіки в цілому, так і правових та економічних методів окремих галузей і видів діяльності регулювання.

Таблиия 1

Підходи до систематизації інструментів державного регулювання економіки в изілому та окремих галузей зокрема

\begin{tabular}{|c|c|c|c|}
\hline Автор & $\begin{array}{c}\text { Об’єкт } \\
\text { державного } \\
\text { регулювання }\end{array}$ & $\begin{array}{c}\text { Методи та } \\
\text { форми } \\
\text { державного } \\
\text { регулювання }\end{array}$ & Інструменти державного регулювання \\
\hline 1 & 2 & 3 & 4 \\
\hline \multirow{2}{*}{$\begin{array}{c}\text { Павлова Г.С. } \\
{[15]}\end{array}$} & \multirow{2}{*}{$\begin{array}{l}\text { аграрний } \\
\text { комплекс }\end{array}$} & адміністративні & $\begin{array}{l}\text { встановлення порядку реєстрації та } \\
\text { ліцензування } \\
\text { регламентація діяльності підприємств, } \\
\text { стандартизація та сертифікація }\end{array}$ \\
\hline & & економічні & $\begin{array}{l}\text { фінансово-кредитне, } \\
\text { бюджетне, інвестиційне регулювання, } \\
\text { регулювання цін та розвитку } \\
\text { регіональних ринків }\end{array}$ \\
\hline \multirow{6}{*}{$\begin{array}{c}\text { Хайтаєв Б.Т. } \\
{[16]}\end{array}$} & \multirow{6}{*}{$\begin{array}{l}\text { аграрний } \\
\text { комплекс }\end{array}$} & $\begin{array}{c}\text { правове, } \\
\text { нормативне та } \\
\text { інформаційне } \\
\text { забезпечення }\end{array}$ & $\begin{array}{l}\text { закони, накази та постанови, інструкції, } \\
\text { нормативи, норми тощо }\end{array}$ \\
\hline & & $\begin{array}{l}\text { інфраструктурн } \\
\text { е забезпечення }\end{array}$ & $\begin{array}{l}\text { маркетингова система обслуговування, } \\
\text { система оптових та роздрібних ринків, } \\
\text { товарні біржі тощо }\end{array}$ \\
\hline & & $\begin{array}{c}\text { регулювання } \\
\text { ринку } \\
\text { продукції }\end{array}$ & $\begin{array}{l}\text { квоти, закупівельні та товарні } \\
\text { інтервенції, митні збори та квоти тощо }\end{array}$ \\
\hline & & $\begin{array}{c}\text { цінове } \\
\text { регулювання }\end{array}$ & $\begin{array}{lll}\text { ринкові, } & \text { гарантовані, } & \text { цільові, } \\
\text { орієнтовані ціни, надбавки до ціни } \\
\text { тощо }\end{array}$ \\
\hline & & $\begin{array}{l}\text { фінансові } \\
\text { методи }\end{array}$ & $\begin{array}{l}\text { фінансування цільових програм, } \\
\text { підготовки кадрів, НДККР, бюджетні } \\
\text { позики, дотації, компенсації тощо }\end{array}$ \\
\hline & & $\begin{array}{c}\text { грошово- } \\
\text { кредитні } \\
\text { методи } \\
\end{array}$ & $\begin{array}{l}\text { регулювання облікових ставок за кредитами } \\
\text { та ставок рефінансування комерційних } \\
\text { банків, цільове кредитування тощо } \\
\end{array}$ \\
\hline
\end{tabular}




\begin{tabular}{|c|c|c|c|}
\hline & & & Продовження табл. 1 \\
\hline 1 & 2 & 3 & 4 \\
\hline \multirow{2}{*}{$\begin{array}{c}\text { Москвічова } \\
\text { О.С. } \\
\text { [229, } \\
\text { с. } 48-49]\end{array}$} & \multirow[b]{2}{*}{$\begin{array}{l}\text { кредитний } \\
\text { сектор }\end{array}$} & $\begin{array}{c}\text { рефінансування } \\
\text { банків }\end{array}$ & $\begin{array}{l}\text { облікова, відсоткова ставка, строки } \\
\text { кредитування, розмір кредиту, } \\
\text { особливі умови рефінансування, } \\
\text { резервні вимоги, контроль за цільовим } \\
\text { використанням }\end{array}$ \\
\hline & & $\begin{array}{c}\text { кредитування } \\
\text { реального } \\
\text { сектору }\end{array}$ & $\begin{array}{l}\text { процентна ставка, } \\
\text { кредитування, розмір кредиту, валюта } \\
\text { кредиту, мораторії i заборони, } \\
\text { державні гарантії, пільгові режими } \\
\text { кредитування, вимоги до оцінки } \\
\text { кредитоспроможності, вимоги до } \\
\text { формування резервів }\end{array}$ \\
\hline \multirow{3}{*}{$\begin{array}{c}\text { Бабаченко } \\
\text { Л.В. } \\
\text { [19] }\end{array}$} & \multirow{3}{*}{$\begin{array}{c}\text { автотранспо } \\
\text { ртні } \\
\text { пасажирські } \\
\text { перевезення }\end{array}$} & адміністративні & $\begin{array}{l}\text { кваліфікаційні, технічні, організаційні та } \\
\text { інші вимоги до провадження } \\
\text { господарської діяльності } 3 \text { надання } \\
\text { послуг } 3 \text { перевезення пасажирів } \\
\text { автомобільним транспортом; стандарти } \\
\text { роботи в галузі пасажирських } \\
\text { автотранспортних перевезень }\end{array}$ \\
\hline & & економічні & $\begin{array}{l}\text { ефективний перерозподіл фінансових } \\
\text { ресурсів (система податків та зборів); } \\
\text { податкові пільги для пасажирських } \\
\text { автопідприємств, що сприяє розвитку } \\
\text { підприємства; посилення державних } \\
\text { гарантій перевізникам (субвенції), які } \\
\text { надають послуги пільговим категоріям } \\
\text { населення, виконуючи соціальну } \\
\text { функцію; створення конкурентних } \\
\text { умов фунцціонування галузі } \\
\text { пасажирського автотранспорту; } \\
\text { державно-приватне партнерство }\end{array}$ \\
\hline & & правові & $\begin{array}{l}\text { законодавча база; } \\
\text { Транспортна стратегія України навна } \\
\text { період до 2020 року; Транспортна } \\
\text { політика України та ії наближення до } \\
\text { норм Свропейського Союзу; програми } \\
\text { органів виконавчої влади щодо розвитку } \\
\text { видів транспорту і дорожнього } \\
\text { господарства на періоддо } 2015 \text { р. }\end{array}$ \\
\hline
\end{tabular}




\begin{tabular}{|c|c|c|c|}
\hline & & & Продовження табл. 1 \\
\hline 1 & 2 & 3 & 4 \\
\hline \multirow{6}{*}{$\begin{array}{l}\text { Кабаченко } \\
\text { Г.С. } \\
\text { [17] }\end{array}$} & \multirow{6}{*}{ ринок праці } & правові & 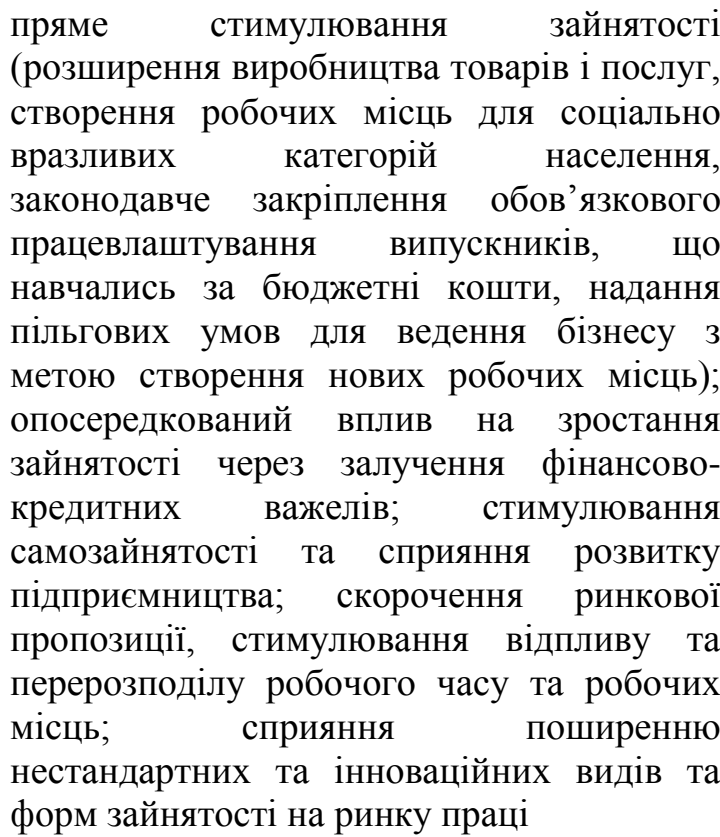 \\
\hline & & організаційні & $\begin{array}{l}\text { державні програми, стандарти, статистичні } \\
\text { норми i показники, ліцензування та } \\
\text { сертифікація, квотування }\end{array}$ \\
\hline & & економічні & $\begin{array}{l}\text { iнструменти податкового механізму } \\
\text { (податкові пільги, пов'язані зі звільненням } \\
\text { від виплат у соціальні фонди, з прийнятям } \\
\text { на роботу неконкурентоспроможни } \\
\text { верств населення, 3 професійним } \\
\text { навчанням тощо); } \\
\text { кредитні інструменти (преференції на } \\
\text { виконання державних програм, фінансові } \\
\text { штрафи при порушенні порядку } \\
\text { квотування робочих місць для } \\
\text { неконкурентоспроможних } \\
\text { населення, дерств } \\
\text { непрацюючим громадянам тощо) }\end{array}$ \\
\hline & & правові & $\begin{array}{l}\text { закони, укази Президента } \text { України, } \\
\text { постанови Кабінету Міністрів України, } \\
\text { розпорядження міністрів, відомств, } \\
\text { комітетів, рішення місцевих адміністрацій }\end{array}$ \\
\hline & & адміністративні & $\begin{array}{l}\text { ліцензування, квотування, стандартизація } \\
\text { та сертифікація, державні замовлення та } \\
\text { контракти, адміністративні заборони та } \\
\text { обмеження, регламентація діяльності } \\
\text { підприємств }\end{array}$ \\
\hline & & економічні & $\begin{array}{l}\text { бюджетно-податкова політика, грошово- } \\
\text { кредитна політика, митна, цінова політика, } \\
\text { протекшіонізм на продовольчому ринку }\end{array}$ \\
\hline
\end{tabular}




\begin{tabular}{|c|c|c|c|}
\hline & & & Продовження табл. 1 \\
\hline 1 & 2 & 3 & 4 \\
\hline \multirow{2}{*}{$\begin{array}{l}\text { Матвієнко } \\
\text { В.В. } \\
\text { [18] }\end{array}$} & \multirow[t]{2}{*}{ транспорт } & $\begin{array}{c}\text { транспортна } \\
\text { політика }\end{array}$ & 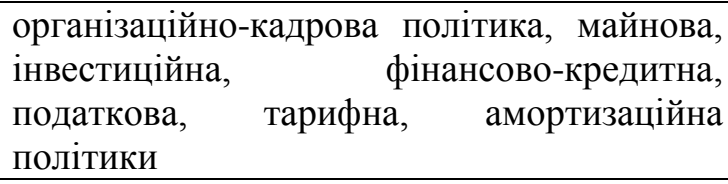 \\
\hline & & $\begin{array}{c}\text { оперативне } \\
\text { управління } \\
\text { транспортом } \\
\end{array}$ & $\begin{array}{l}\text { адміністративно-дозвільна діяльність, } \\
\text { державний нагляд, адміністративно- } \\
\text { розпорядча діяльність }\end{array}$ \\
\hline \multirow[b]{2}{*}{$\begin{array}{l}\text { Степанов } \\
\text { В.Ю. } \\
\text { [20] }\end{array}$} & \multirow[b]{2}{*}{ транспорт } & $\begin{array}{c}\text { адміністративно- } \\
\text { правові }\end{array}$ & 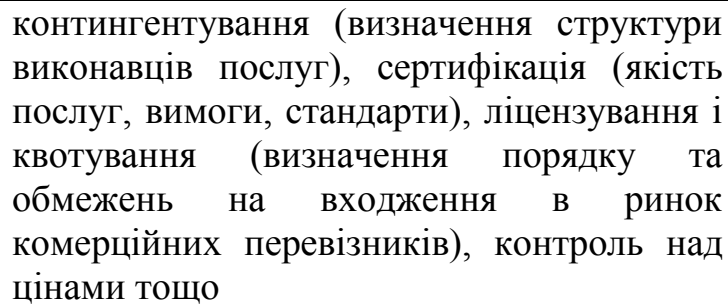 \\
\hline & & економічні & $\begin{array}{l}\text { субвенції, або прямі субсидії, які } \\
\text { включають в себе дотації та доплати } 3 \\
\text { бюджетів різних рівнів на компенсацію } \\
\text { доходів виконавцям послуг, пільгові } \\
\text { кредити, податкові пільги, лізинговий } \\
\text { інструментарій для відновлення зношеної } \\
\text { виробничо-технічної бази транспорту, а } \\
\text { також важелі податкової, амортизаційної, } \\
\text { митно-тарифної політики }\end{array}$ \\
\hline
\end{tabular}

Щодо державного регулювання діяльності транспортного комплексу, то в значній кількості досліджень акцентується увага на необхідності адресного державного фінансування проектів залізничного транспорту, бюджетного субсидіювання пасажирського комплексу, тарифному регулюванні перевезень, розвитку спільного фінансування перевезень 3 місцевими бюджетами тощо. Зважаючи на прийнятий напрямок реалізації реформ на залізничному транспорті та необхідність інноваційної модернізації галузі, модель державного регулювання стратегічного розвитку залізниць має враховувати пріоритетні напрями розвитку галузі, розкриваючи інструменти формування стратегічних переваг за такими складовими розвитку, як інноваційно-виробнича, інвестиційна, соціальна, енергетична, екологічна та міжнародна складова (табл. 2). Так, інструментами державного регулювання процесів забезпечення інноваційнотехнологічного лідерства залізничного транспорту пропонується розглядати

$$
\text { - нормативно-правове }
$$

забезпечення інноваційної діяльності;

$$
\text { - Кодекс міжгалузевого }
$$

інноваційного співробітництва;

- державні програми підтримки інновацій;

$$
\text { - спеціальний }
$$

режим

оподаткування (податкові канікули, дотації, преференції, зниження розміру податку на прибуток);

- бюджетне фінансування;

- державне замовлення на

інновації;

- пільговий режим на імпорт інноваційного обладнання;

- спрощення ліцензування та патентування;

- формування загальнодержавної бази інноваційних технологій для потреб залізниць. 


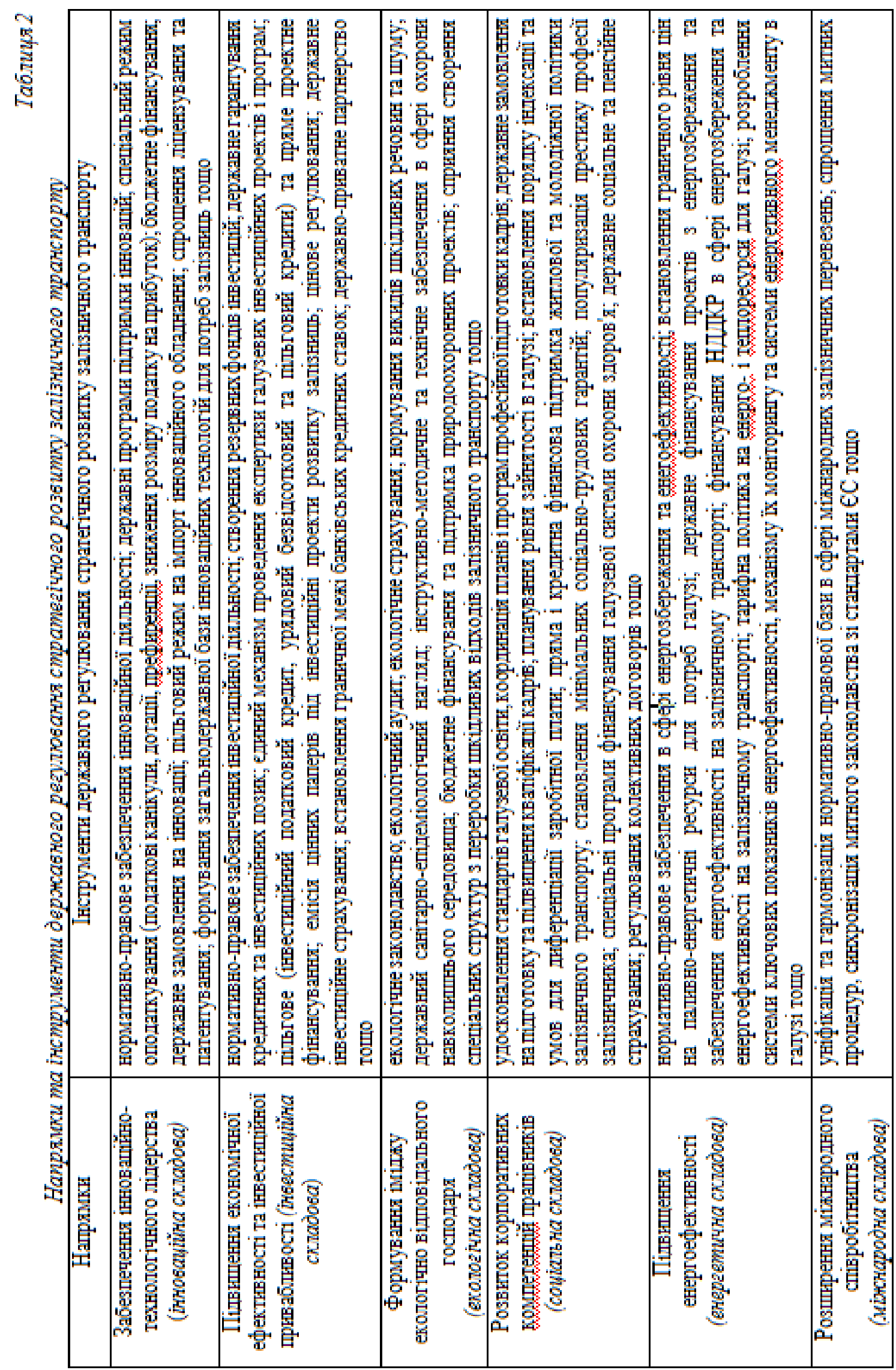

Вісник економіки транспорту і промисловості № 69,2020 
До інструментів державного регулювання процесів підвищення енергоефективності на залізничному транспорті належать:

\section{- нормативно-правове}

забезпечення в сфері енергозбереження та енергоефективності;

- встановлення граничного рівня цін на паливно-енергетичні ресурси для потреб галузі;

- державне фінансування

проектів 3 енергозбереження та забезпечення енергоефективності на залізничному транспорті;

- фінансування НДДКР у сфері енергозбереження та енергоефективності;

- тарифна політика на енерго- i теплоресурси для галузі;

- розробка системи ключових показників енергоефективності, механізму їх моніторингу та системи енергетичного менеджменту.

Для підвищення економічної ефективності та інвестиційної привабливості залізничного транспорту 3 боку держави необхідним $є$ :

\section{- нормативно-правове}

забезпечення інвестиційної діяльності; інвестицій;

- створення резервних фондів

- державне

гарантування

кредитних та інвестиційних позик;

- єдиний механізм проведення експертизи галузевих інвестиційних проектів і програм;

- пільгове

(інвестиційний

податковий кредит, урядовий безвідсотковий та пільговий кредити) та пряме проектне фінансування;

- емісія цінних паперів під інвестиційні проекти розвитку залізниць;

- цінове регулювання;

- державне інвестиційне

страхування;

- встановлення граничної межі

банківських кредитних ставок;

- державно-приватне

партнерство.
Інструментами

державного

регулювання розвитку корпоративних компетенцій працівників повинні бути:

- удосконалення

стандартів

галузевої освіти, координація планів і програм професійної підготовки кадрів;

- державне замовлення на

підготовку та підвищення кваліфікації кадрів;

- планування рівня зайнятості в

галузі;

- встановлення

порядку

індексації та умов для диференціації заробітної плати;

- пряма i кредитна фінансова

підтримка житлової та молодіжної

політики залізничного транспорту;

- становлення мінімальних

соціально-трудових гарантій;

- популяризація

престижу

професії залізничника;

- спеціальні

програми

фінансування галузевої системи охорони здоров'я;

- державне соціальне та пенсійне страхування;

- регулювання колективних

договорів.

Для формування іміджу екологічно відповідального господаря державне втручання в діяльність залізниць має виражатися через:

- екологічне законодавство;

- екологічний аудит;

- екологічне страхування;

- нормування викидів шкідливих

речовин та шуму;

- державний санітарно-

епідеміологічний нагляд;

- інструктивно-методичне та

технічне забезпечення в сфері охорони навколишнього середовища;

- бюджетне фінансування та

підтримка природоохоронних проектів;

- сприяння

створення

спеціальних структур 3 переробки

шкідливих відходів залізничного

транспорту.

Інструментами державного

регулювання процесів розширення

Вісник економіки транспорту і промисловості № 69, 2020 
міжнародного співробітництва

залізничного транспорту є:

- уніфікація та гармонізація нормативно-правової бази в сфері міжнародних залізничних перевезень;

- спрощення митних процедур, синхронізація митного законодавства зі стандартами ЕС тощо.

Практична реалізація даної моделі дозволить забезпечити інноваційнотехнологічне лідерство, підвищити енерго-, економічну ефективність та інвестиційну привабливість галузі, розвиток корпоративних компетенцій працівників, сформувати імідж екологічно відповідального господаря та розширити міжнародне співробітництво залізничного транспорту. На загальнодержавному рівні інтегрований розвиток українських залізниць сприятиме приросту науковотехнічних знань та активізації інноваційного підприємства в країні, зростанню рівня зайнятості та соціальних стандартів населення, підвищенню якості транспортної інфраструктури та мобільності громадян, зростанню рівня ВВП та бюджетних платежів, активізації промислового потенціалу та зниження рівня імпортозалежності, покращенню інвестиційного рейтингу та рівня конкурентоспроможності України на світовому ринку.

Висновки. У надзвичайно складний реформаційний період для залізничного транспорту держава повинна бути активним учасником реалізації стратегічних змін, забезпечуючи значну підтримку галузі в процесах трансформації іï системи функціонування. Грунтуючись на аналізі закордонних моделей державного регулювання діяльності залізниць та недоліках у програмних документах щодо реформування залізничного транспорту в Україні, подано пріоритетні напрями розвитку галузі та в комплексі розкрито інструменти формування стратегічних переваг залізниць за такими складовими розвитку, як інноваційно-виробнича, інвестиційна, соціальна, енергетична, екологічна та міжнародна складова.

\section{СПИСОК ЛІТЕРАТУРИ}

1. Дикань В. Л. Удосконалення механізмів державного управління розвитком залізничної галузі України у євроінтеграційному векторі / В. Л. Дикань, Г. С. Островерх // Вісник економіки транспорту і промисловості. - 2018. №62. - C. 11-19.

2. Полякова О. М. Сучасні тенденції розвитку транспортнологістичної інфраструктури в Україні i світі / О. М. Полякова, О.В. Шраменко // Вісник економіки транспорту i промисловості. - 2017. - № 58. - С. 126134.

3. Корінь М.В. Розвиток інфраструктури залізничного транспорту в умовах транскордонного співробітництва: монографія / М.В. Корінь. - Харків: УкрДУЗТ, 2019. - 401 с.

4. Обруч Г. В. Забезпечення розвитку потенціалу конкурентоспроможності вагонобудівних підприємств України: дис. ... канд. екон. наук: 08.00.04 «Економіка та управління підприємствами (за видами економічної діяльності)». Український державний університет залізничного транспорту. Харків, 2017. - 265 с.

5. Токмакова I. B. Забезпечення гармонійного розвитку залізничного транспорту України : монографія / I.B. Токмакова. - X.: УкрДУЗТ, 2015. - 403 с.

6. Овчиннікова В. О. Стратегічне управління розвитком залізничного транспорту України: монографія / В. О. Овчиннікова- Х.: УкрДУЗТ, 2017. - 427 с.

7. Литвин Ю.О. Методи державного регулювання сільського господарства / Ю.О. Литвин // Науковий вісник Академії муніципального управління. Серія : Управління. - 2012. Вип. 4. - С. 127-135. 
8. Положенцева К. Л. Методологічні основи державного регулювання агропромислового комплексу регіону / К. Л. Положенцева [Електронний ресурс]. - Режим доступу: http://dspace.univer.kharkov.ua/handle/12345 6789/4502.

9. Динаев Т.Н. Развитие государственного регулирования предпринимательской деятельности на современном этапе: автореф. дисс. на соиск. учен. степени канд. экон. наук; специальность: 08.00.05 - экономика и управление народным хозяйством / Динаев Тахир Нажмудинович. - М., 2007. $-27 \mathrm{c}$.

10. Борисенко

O.

$\Pi$. Комплексний підхід до систематизації методів державного регулювання зовнішньоекономічної діяльності / О. П. Борисенко // Економіка та держава. 2012. - № 12. - C. 115-117.

11. Гончаренко І.Г. Державний механізм регулювання соціальноекономічного розвитку: теорія, методологія та практика: дис. на здобуття наук. ступеня докт. екон. наук; спеціальність: 25.00.02 - механізми державного управління / Гончаренко Ірина Георгіївна. - Маріуполь, 2015. - 390 с.

12. Грабельников А.В. Аналіз методів державного регулювання транспортної системи / А.В. Грабельников // Акуальні проблеми державного управління. - 2011. - № 2 (40). - С. 100 107.

13. Плікус І.Й. Державне регулювання діяльності підприємств пасажирського автотранспорту / I.Й. Плікус // Фінанси України. - 2005. № 4. - С. 133 -139.

14. Дикань О.В. Удосконалення державного регулювання транспортного комплексу України: автореф. дис. на здобуття наук. ступеня канд. екон. наук; спеціальність: 08.02.03 - організація управління, планування i регулювання економікою / О.В. Дикань. - Харків, 2006. $-20 \mathrm{c}$.
15. Павлова Г.Є. Методи державного регулювання аграрного сектору економіки України / Г.С. Павлова // Інвестиції: практика та досвід. - 2013. № 9. - С. 47-49.

16. Хайтаев

Б.T.

Совершенствование государственного регулирования агропромышленного комплекса региона (на примере Чеченской республики): дисс. на соиск. учен. степени канд. экон. наук; специальность: 08.00.05 - экономика и управление народным хозяйством: экономика, организация и управление предприятиями, отраслями, комплексами - АПК и сельское хозяйство / Хайтаев Бислан Туханович. - Нальчик, 2016. - 167 c.

\section{7. Кабаченко}

Г.C.

Регулювання ринку праці в умовах трансформації структури зайнятості: дис. на здобуття наук. ступеня канд. екон. наук; спеціальність: 08.00.07 - демографі, економіка праці, соціальна економіка i політика / Кабаченко Ганна Сергіївна. Вінниця, 2017. - 247 с.

18. Матвієнко В.В. Механізм державного управління розвитком залізничної галузі в Україні: дис. на здобуття наук. ступеня канд. наук 3 держ. упр.; спеціальність: 25.00.02 - механізми державного управління / Матвієнко Володимир Васильович. - Маріуполь, 2017. - $256 \mathrm{c}$.

19. Бабаченко Л. В. Формування субсидіарного соціально-економічного потенціалу автотранспортних пасажирських перевезень: автореф. дис. на здобуття наук. ступеня канд. екон. наук; спеціальність: 08.00.03 - економіка та управління національним господарством / Бабаченко Лариса Валентинівна. Чернігів, 2014. - 22 с.

20. Степанов В.Ю. Державне регулювання транспортною сферою / В.Ю. Степанов // Вісник Національного університету цивільного захисту України. Серія : Державне управління. - 2016. Вип. 1. - С. 97-103. 


\section{REFERENCES}

1. Dykan V.L., Ostrooverh G.E. (2018) Udoskonalennya mekhanizmiv derzhavnoho upravlinnya rozvytkom zaliznychnoyi haluzi Ukrayiny u yevrointehratsiynomu vektori [Improvement of the mechanisms of state management of the development of the railway industry of Ukraine in the European integration vector]. Bulletin of the economy of transport and industry. №62. P. 11-19.

2. Polyakova O. M., Shramenko O.V. (2017) Suchasni tendentsiyi rozvytku transportno-lohistychnoyi infrastruktury $\mathrm{v}$ Ukrayini i sviti [Modern tendencies of development of transport and logistics infrastructure in Ukraine and the world]. Bulletin of Economics of Transport and Industry. No. 58. P. 126-134.

3. Korin M.V. (2019) Rozvytok infrastruktury zaliznychnoho transportu $\mathrm{V}$ umovakh transkordonnoho spivrobitnytstva: monohrafiya [Development of railway transport infrastructure in the context of cross-border cooperation: monograph]. Kharkiv: UUofRT. 401 p.

\section{Obruch G.V.}

(2017) Zabezpechennya rozvytku potentsialu konkurentospromozhnosti vahonobudivnykh pidpryyemstv Ukrayiny [Provision of development of the potential of competitiveness of railway car-building enterprises of Ukraine] dis. ... Cand. econom. Sciences: 08.00.04 "Economics and Management of Enterprises (by type of economic activity)". UUofRT. Kharkiv, 265 p.

5. Tokmakova I.V. (2015) Zabezpechennya harmoniynoho rozvytku zaliznychnoho transportu Ukrayiny : monohrafiya [Ensuring the harmonious development of Ukrainian rail transport: monograph]. Kharkiv: UUofRT. 403 p.

6. Ovchynnikova V.A. (2017) Stratehichne upravlinnya rozvytkom zaliznychnoho transportu Ukrayiny: monohrafiya [Strategic management of the development of railway transport of Ukraine: monograph]. Kharkiv: UUofRT. 427 p.
7. Litvin Yu.O. (2012) Metody derzhavnoho rehulyuvannya sil's'koho hospodarstva [Methods of state regulation of agriculture]. Scientific Bulletin of the Academy of Municipal Administration. Series: Management. №4. P. 127-135.

8. Polozhentseva K.L.

(2019)

Metodolohichni osnovy derzhavnoho rehulyuvannya ahropromyslovoho kompleksu rehionu [Methodological bases of state regulation of agro-industrial complex of the region]

URL: http://dspace.univer.kharkov.ua/handle/12345 6789/4502.

9. Dinaev T.N. (2007) Razvytye hosudarstvennoho rehulyrovanyya predprynymatel'skoy deyatel'nosty na sovremennom étape [Development of state regulation of entrepreneurial activity at the present stage] author. diss. on the nipple. scientist. degrees of Cand. econom. Sciences; specialty: 08.00 .05 Economics and Management of National Economy. M. 27 p. 10. Borysenko A.P. (2012) Kompleksnyy pidkhid do systematyzatsiyi metodiv derzhavnoho rehulyuvannya zovnishn'oekonomichnoyi diyal'nosti [Complex approach to systematization of methods of state regulation of foreign economic activity] Economy and State. № 12. P. 115-117.

11. Goncharenko I.G. (2015) Derzhavnyy mekhanizm rehulyuvannya sotsial'no-ekonomichnoho rozvytku: teoriya, metodolohiya ta praktyka [State mechanism of regulation of socio-economic development: theory, methodology and practice] diss. for the sciences. degree doct. econom. Sciences; specialty: 25.00.02 mechanisms of public administration. Mariupol. 390 p.

12. Grabelnikov A.V. (2011) Analiz metodiv derzhavnoho rehulyuvannya transportnoyi systemy [Analysis of methods of state regulation of the transport system] Emergency problems of public administration. № 2 (40). P. 100-107.

13. Plikus I.Y. (2005) Derzhavne rehulyuvannya diyal'nosti pidpryyemstv pasazhyrs'koho avtotransportu [State

Вісник економіки транспорту і промисловості № 69, 2020 
regulation of activity of the enterprises of passenger motor transport] Finance of Ukraine. № 4. P. 133 -139.

14. Dikan O.V.

(2006)

Udoskonalennya derzhavnoho rehulyuvannya transportnoho kompleksu Ukrayiny [Improvement of state regulation of the transport complex of Ukraine] author. diss. for the sciences. degree of Cand. econom. Sciences; specialty: 08.02.03. Organization of Management, Planning and Regulation of Economy. Kharkiv. 20 p.

15. Pavlova G.E. (2013) Metody derzhavnoho rehulyuvannya ahrarnoho sektoru ekonomiky Ukrayiny [Methods of state regulation of agrarian sector of economy of Ukraine] Investments: practice and experience. № 9. P. 47-49.

16. Khaytayev B.T. (2016) Sovershenstvovanye hosudarstvennoho rehulyrovanyya ahropromyshlennoho kompleksa rehyona (na prymere Chechenskoy respublyky) [Improvement of the state regulation of the agro-industrial complex of the region (on the example of the Chechen Republic)] diss. on the nipple. scientist. degrees of Cand. econom. Sciences; specialty: 08.00.05 Economics and Management of National Economy: Economics, Organization and Management of Enterprises, Industries, Complexes Agroindustrial Complex and Agriculture. Nalchik. 167 p.
17. Kabachenko G.S. (2017) Rehulyuvannya rynku pratsi $\mathrm{v}$ umovakh transformatsiyi struktury zaynyatosti [Regulation of the labor market in the conditions of transformation of employment structure] dis. for the sciences. degree of Cand. econom. Sciences; specialty: 08.00.07 demographics, labor economics, social economy and politics. Vinnitsa. $247 \mathrm{p}$.

$$
\text { 18. Matvienko V.V. (2017) }
$$

Mekhanizm derzhavnoho upravlinnya rozvytkom zaliznychnoyi haluzi v Ukrayiny [The Mechanism of Public Administration of Railway Industry Development in Ukraine] Dis. for the sciences. degree of Cand. of sciences from the state. management; specialty: 25.00.02. mechanisms of public administration . Mariupol. $256 \mathrm{p}$.

$$
\text { 19. Babachenko L.V. }
$$

Formuvannya subsydiarnoho sotsial'noekonomichnoho potentsialu avtotransportnykh pasazhyrs'kykh perevezen' [Formation of subsidiary socio-economic potential of road passenger transport] author. diss. for the sciences. degree of Cand. econom. Sciences; specialty: 08.00 .03 Economy and Management of the National Economy. Chernihiv. $22 \mathrm{p}$.

20. Stepanov V.Yu. (2016) Derzhavne rehulyuvannya transportnoyu sferoyu [State regulation of transport sphere] Bulletin of the National University of Civil Defense of Ukraine. Series: Public Administration. №1. P. 97-103. 